\title{
Sınıraşan/Organize Suçlar Bağlamında Avrupa Birliği
}

\author{
Furkan YILDIZ*
}

\begin{abstract}
$\ddot{O Z Z}$
Bu çalışmanın temelde amact, Avrupa Birliği sinırlart içerisinde hem ekonomik hem de politik birçok olumsuz sonuç doğuran organize suç olgusunu inceleyerek, bu yasa dişı aktivitelere dair Birliğe yol haritası çizen Ağır ve Organize Suçlar Değerlendirmeleri içerisindeki değişimleri analiz etmektir. Çalıșma yöntem olarak öncelikle literatür taraması ile organize suç olgusunun kavramsal çerçevesini çizmiş, daha sonra ise Europol tarafindan hazırlanan 2014-2017 ve 20182021 yıllarına ait değerlendirmeleri karşılaştırarak organize suçların Birlik içerisindeki değişimini değerlendirmiş̧tir. Bu karşılaştırmalardan elde edilen en çarpıcı sonuçlardan biri 2014-2017 yıllarına ait politikaların belirlenmesine yönelik değerlendirmelerde çevre suçları, terörün finansmanı ve kara para aklama suçları odaklanılması gereken suçlar arasında geri planda kalmıştır. Fakat Brüksel'de ve Paris'te gerçekleştirilen terör eylemlerinin ardından Europol özellikle terörün finansmanı konusunu ön plana almıştır.

Bu çalışma, çok yönlü karakteriyle hem organize suç olgusunu değerlendirmiş hem de daha önce karşılaştırmalı olarak incelenmeyen iki ardışık dönemi organize suçlar bağlamında analiz etmiştir.
\end{abstract}

Anahtar Kelimeler: Organize Suçlar, Europol, SOCTA, Avrupa Birliği

JEL Sinıflandirması: F50, K33

\section{European Union In The Context Of Transnational/Organized Crimes}

\begin{abstract}
The main purpose of this study is to analyze the changes in the Severe and Organized Crime Assessments that guide the Union on these illegal activities by examining the phenomenon of organized crime that has many economic and political negative consequences within the borders of the European Union. As a method, first of all, the study has drawn the conceptual framework of organized crime phenomenon by examining the related literature, and then evaluated the changes of organized crime tendencies within the Union by comparing the evaluations of 2014-2017 and 20182021 prepared by Europol. One of the most striking results obtained from these comparisons is while the environmental crimes, criminal finance and money laundering issues have been laid into background in the assessment period between 2014 and 2017, after the terrorist attacks in Brussels and Paris, particularly the criminal finance or financial supports to terrorist activities issues have been brought to the fore the assessment period for 2018-2021 by Europol.

This study, with its versatile character, both evaluated the phenomenon of organized crime and analyzed two consecutive periods in the context of organized crime, which were not compared before.
\end{abstract}

Key Words: Organized Crime, Europol, SOCTA, European Union

JEL Classification: F50, K33

\footnotetext{
*Dr. Öğr. Üyesi, Kırklareli Üniversitesi Sosyal Bilimler MYO, Dış Ticaret Bölümü.

furkanyildiz1985@hotmail.com, ORCID Bilgisi: 0000-0003-1533-222X
}

(Makale Gönderim Tarihi: 12.04.2020 / Yayına Kabul Tarihi: 11.08.2020) 


\section{GİRIŞ}

Asıl amacı ulusal sınırlara bakılmaksızın kâr elde etmek olan ve sürekli yasadış1 faaliyette bulunan herhangi bir girişim veya kişi grubu olarak Interpol tarafından tanımlanan organize suç, dünyanın her yerinde ve farklı şekillerde ortaya çıkabilen kapsamlı ve büyük suç girişimleridir (Interpol, 1998: De Vito, 2005: xi). Ülkesel veya bölgesel eğilimler doğrultusunda doğan talebi karşılamak için yasa dışı yollar kullanarak arz oluşturan örgütler de bu tür suçların failleri durumundadır. Küreselleşmenin getirilerinin, bölgesel taleplerin ve en önemlisi suç ilişki ağlarının gelişmesi neticesinde ortaya çıkan bu suçlar dünyanın farklı bölgelerini etkilediği kadar Avrupa Birliği (AB) sınırlarında da kendini göstermektedir.

$\mathrm{Bu}$ çalışma, sınıraşan organize suçlar bağlamında AB'nin içinde bulunduğu durumu dönemsel olarak Europol tarafından yayınlanan Ağır ve Organize Suçlar değerlendirmesi çerçevesinde inceleyerek AB'nin hem politik, hem de operasyonel anlamda hedef aldığı suçlara yaklaşımını inceleyecektir. Bu doğrultuda, daha kapsamlı bir değerlendirme yapabilmek adına literatürde ki organize suçlara bakış incelenecek ve uluslararası anlamda en kapsamlı çatı metin olan Birleşmiş Milletler Sınıraşan Organize Suçlar Sözleşmesi değerlendirilecektir.

Kavramsal çerçevenin ardından, AB sınırları için ortaya çıkan organize suç faaliyetlerinin doğası ve eğilimleri değerlendirilerek AB'nin bu suçlara bakışı ile ilgili genel bir çerçeve çizilecektir. Kavramsal çerçevenin sunduğu temeller üzerine inşa edilen AB'nin yaklaşımları, Europol'ün 2014-2017 ve 2018-2021 yılları arasında organize suçlara dair ortaya koyduğu iki değerlendirme doğrultusunda incelenecektir. $\mathrm{Bu}$ inceleme, hem organize suç örgütlerinin esneklik ve yeni durumlara adaptasyonlarının hızını, hem de $A B$ 'nin bu süreç içerisinde ki tutumlarını gözler önüne serecektir.

\section{KAVRAMSAL OLARAK SINIRAŞAN SUÇLAR ve KÜRESEL BİR YAKLAȘIM}

Kriminoloji litertüründe ve resmi kaynaklarda organize suç kavramının temellerine, yapısına ve davranışsal özelliklerine işaret eden birçok tanım yapılmıştır (Hall, 2012:369). Fakat yapılan tanımlar, ampirik olarak kompleks ve değişkenleri ve çeşitleri fazla olan bu kavramı açıklamakta sınırlı kalmıştır. Örneğin, Albanese'in organize suçlar kavramının içeriğini sadece yasa dışı eylemlere bağlaması konusu literatürün içerisinde organize suçların hayata geçirilebilmesi için aslında yasal işlere olan ihtiyacın göz ardı edildiği konusunu ortaya çıkartmıştır (Albanese, 2005:10). Bu konuyla ilgili olarak Nordstorm organize suç kavramı içerisinde işlenen suçların aslında yasa dışı işlerden daha çok yasal işlere bağımlı olduğunu vurgulamış ve kara para aklama suçunun gerçekleştirilebilmesi için yasal bir işletme veya finans kurumunun varlığına olan ihtiyacın altını çizerek konuyu örneklendirmiştir (Nordstorm, 2007). Dorr ve Simpson (1931:442-443), organize suçların iki alanda ortaya çıktığından bahsetmiş ve bu alanları dolandırıcılık ve şantaj olarak belirtmişlerdir. Fakat bu çalışmada organize suçların etnik ve davranışsal boyutlarını ele almaktan yoksun 
kalmıştır (Madsen, 2009:13). Daha güncel ve daha genel geçer bir tanımlama da Birleşmiş Milletler'in 2010 y1lında hazırlamış olduğu "Suçun Küreselleşmesi: Sınıraşan Organize Suç Tehdit Değerlendirmesi" adlı çalışma içerisinde yapılmıştır. Sınıraşan Organize Suçlar Sözleşmesi'nin sunduğu tanımlar 1şığında "organize suç" konusunda daha geniş kapsamlı bir tanımlama yapılmış ve organize suç kavramını "üç veya daha fazla kişinin para kazanmak amacıyla işlediği suç veya suçlar olarak" ifade etmiştir (UNODC, 2010:19).

1800'lü yıllarda bile varlığından söz edilen organize suçlar, daha evvel de belirtildiği gibi küreselleşmenin katkısıyla artık ağırlıklı olarak sınır içerisinde yürüttügü faaliyetlerini sınır dışlarınada taşımışlardır. İşte bu noktada, sınıraşan kavramına kısa bir bakış, organize suçların nasıl sınıraşan organize suçlar konseptine döndüğünü anlamamıza yardımcı olacaktır. Organize suçların iki yüz yıldan fazla bir geçmişi olmasına rağmen, sınıraşan suçlar tabiri 1970'li yıllarda kriminoloji literatürüne girmiştir (Sebatino, 2016:63; Felsen ve Kalaitzidis, 2005:5). Günümüzde ise sınıraşan suçlar sadece kriminoloji alanının değil toplumun, politika yapıcıların ve kolluk güçlerinin sıkça kullandığı bir kavram haline gelmiştir. Bu noktada, "sınıraşan" ve "uluslararası" kavramları birbirleri yerine kullanılabilir olarak yorumlanmıştır (Açıklama 1). Fakat genel kullanımda birbirlerinin yerine kullanılması çokta doğru değildir. Sınıraşan suçlar kavramı suç örgütlerini ve yapılarını anlamamı noktasında sosyolojik bir yapıya ve sınıraşan suç aktörlerinin hareket alanı olan uluslararası çevreyi şekillendiren ulus-devletler ve politikalarla ilgili olduğu içinde politik bir konuya işaret etmektedir (Serrano, 2002:16).

Sınıraşan suçların Avrupa'ya etkilerine geçmeden evvel, aslında bu tür suçların uzunca bir dönemdir varlığını sürdürmekte olduğunu söylemek gerekmektedir. İçinde bulunduğumuz dönemde, hem uluslararası hem de ulusal mevzuatlarda üzerinde durulan suçlardan olan kara para aklama, uyuşturucu ticareti gibi suçlar bundan 100 yı önce dikkate değer bir şekilde ne uluslararası ne de ulusal gündemde yer işgal edemiyordu (Andres, 2002:39: Nadelmann, 1993). Fakat normların sessizliği, bu tür suçların yok olduğu anlamına gelmemektedir. $\mathrm{Bu}$ tür suçlar sadece modern diye nitelendirilen zamanlarda değil tarihin en eski dönemlerinde bile varlığını göstermiştir. Literatür içerisinde konu ile ilgili olarak üç suç sınıraşan suçların karakteristik özelliklerini barındırdıklarından dolayı bu tür suçların ilk örnekleri olarak karşımıza çıkmaktadır. Bu suçlar, geçmişi antik dönemlere uzanan kölelik ve korsanlık, bu iki suça göre daha genç olan afyon kaçakçıllğı suçlarıdır (Felsen ve Kalaitzidis, 2005:7-12: Wilt, 2014: Tom, 2012). Uzun bir geçmişe sahip olan bu tür suçlar özellikle Soğuk Savaş sonrası dönemde oluşan "yenidünya düzeni" içerisinde daha önce olmadığı kadar dikkat çeker hale gelmişlerdir. Williams (2012), sınıraşan organize suçları küreselleşme sürecinden fayda sağlayan bir olgu olarak tanımlar. Konuyla ilgili olarak, iki kutuplu dünya düzeninden sonra, küreselleşmenin dünyayı "küresel bir köy" haline getirerek uluslararası ticaretin ve ticari malların hareketliliğini arttırdığını ama bu hareketliliğin yasal olmayan ticareti de kontrol edilemez hale getirdiğini söylemek mümkündür (Shelly, 1995:465; Wright, 2006:73). Bir diğer değişle, paranın 
dolaşımında ve ticari malların hareketliliğinde sınırların ortadan kalkması sınırları geçen düzeyde bir yasadışı ticareti de tetiklemiştir. Konunun özüne bakacak olursak, Williams'in açıklaması küreselleşmenin organize suç faaliyetleriyle ilişkisini etkilerini gözler önüne çıkartmıştır. Williams'a göre;

"Küreselleşmenin sosyolojik etkisine baktığımız zaman, bazı olumsuzlukları ortaya çıkarttığını görmekteyiz. Küreselleşme sadece kazananların değil aynı zamanda da kaybedenlerin olduğu bir süreçtir. Küreselleşmenin yıkıcı etkisi, dünyanın çeşitli yerlerinde yüksek oranlı eşitsizlik ve yoksulluk olarak ortaya çıkmıştır. Bu durumun asıl sebepleri yetersiz firsatlar ve aşırı derece de orantısız gelir dağılımıdır. Netice olarak da bu durumlar insanları organize suç faaliyetlerine itmektedir." (Williams, 2012).

Küreselleşmenin artan etkisi 90'lı yıllarda, sınıraşan suçların ilerleyen yıllarda daha uluslararası bir karakter kazanmasının temellerini oluşturmuştur. Sınıraşan organize suçlardaki bu artışta sadece yasal yolla yapılan ve yürütülen uluslararası ticaretin artması değil aynı zamanda da kullanımlarında ciddi artışlar görülen hava yolu taşımacılığı, telekomünikasyon teknolojileri ve bilgisayar teknolojileri de artan ticari ilişkiler kadar etkili olmuştur (Gachuz, 2016; Mittelman, 1999:105; Shelly, 1995:465).

1990'larda Sovyetler Birliği'nin dağılması ve yeni devletlerin ortaya çıkmasına bağlı olarak üye sayılarının artması ile Birleşmiş Milletlerin öncelikli konuları bu yöne kaymış olmasına rağmen, Amerika Birleşik Devletleri ve Avrupa artan sınıraşan suçlara dikkat kesilmiş durumdaydı (Felsen ve Kalaitzidis, 2005:14). Nitekim, Birleşmiş Milletler'in 50. kuruluş yılında, Birleşik Devletler Başkanı Bill Clinton, Birleşmiş Milletler'i sınıraşan suçlarla ilgili işbirliği konusunda teşvik etmiş ve 1996 yılında Birleşik Devletler sınıraşan organize suçları ulusal güvenlik konularının başına taşımıştır (Lupsha, 1996:27; Serrano, 2002:27). 1997 yılında Birleşmiş Milletler, sınıraşan organize suçlar ile ilgili bir sözleşme taslağı üzerinde çalışmalarına başladı ve nihayetinde $15 \mathrm{Kasım} 2000$ 'de Birleşmiş Milletler Sınıraşan Organize Suçlar Sözleşmesi ve üç ek Protokol Genel Kurul da kabul edildi (Açıklama 2).

Sözleşme, sınıraşan organize suçlar konusunda ilk uluslararası ve büyük oranda fikir birliğine varılmış ilk adımdır. Sözleşme, suç olarak sayma, uluslararası işbirliği, teknik destek ve uygulama konularının altını çizerek, sınıraşan organize suçlar bağlamında bir çerçeve oluşturmuştur (Vlassis, 2002). Sözleşme, "organize suç" durumuyla üç tutum çerçevesinde baş etmeye çalışmıştır. Sözleşme m.2(a-c) bahsi geçen üç tutumu şu şekilde tanımlamıştır:

a. "Organize suç örgütü" kavramını, doğrudan veya dolaylı olarak mali veya diğer bir maddi çıkar elde etmek amacıyla belli bir süreden beri var olan ve bu Sözleşmede belirtilen bir veya daha fazla ağır suç veya yasadışı eylemi gerçekleştirmek amaciyla birlikte hareket eden, üç veya daha fazla kişiden oluşan yapılanmış bir grup olarak tanımlamıştır.

b. "Ağır suç", dört yıl veya daha fazla hürriyetten mahrumiyeti veya daha ağır bir cezayı gerektiren bir suçu oluşturan davranış olarak belirtilmiştir. 
c. "Yapılanmış grup" belirli bir suçu derhal işlemek için tesadüfi olarak oluşturulmamış ve üyelerinin rollerinin şeklen belirlenmesi şartı olmayan, üyeliğinin devamlılığı veya gelişmiş bir yapısı olması gerekmeyen bir grup olarak ifade edilmiştir.

Sözleşmenin üzerinde durduğu tanımlara eleştirel bir gözle baktığımızda, özellikle madde 2(c) "yapılanmış grup" konusunda geniş ve çerçevesi tam belli olmayan bir kapı açmıştır. Sözleşmenin hazırlık aşamasında da aslında beklenti bu tanımın geniş bir şekilde yorumlanmasıdır. $\mathrm{Bu}$ doğrultuda, tanım, hem hiyerarşik ve detaylı olarak oluşturulmuş gruplar için, hem de grup üyelerinin rollerinin açık bir şekilde ortaya konmadığı hiyerarşik yapıya sahip olmayan gruplar için kullanılacak bir biçimde oluşturulmuştur. Fakat bu nokta, retorik olarak sözleşmede bahsedilen ancak pratikte anlamsız olarak kalmıştır (Orlova ve Moore, 2005:283). Sözleşme, bir standart oluşturabilmek adına madde 2(b) içerisinde "ağır suç" olarak nitelendirilen suçların kapsamını ortaya koymuştur (Vlassis,2002:90). Sözleşmeye göre, örgütlü bir suç grubuna katılmak (m.5), kara para aklamak (m.6), yolsuzluk (m.8) ve adaletin engellenmesi (m.23) suçlarını konu ile ilgili temel suçlar olarak belirtmiştir.

Madde 2(a) içerisinde ele alınan "organize suç örgütü" tanımında ise bir veya daha fazla ağır suçu gerçekleştirmek maksadıyla hareket etmek konusu üzerinde durulmuştur. Bu noktada, şu soru ortaya çıkmaktadır: "organize suç örgütlerini diğer suç örgütlerinden nasıl ayıracağız? Organize suç örgütlerini diğer suç topluluklarından ayıran konu, organize grupların Sözleşme tarafından "ağır suç" olarak ifade edilen suçları, daha sistematik ve süreklilik arz eden bir şekilde ve bu suçları ticari bir iş olarak sürdürmeleridir (Woodiwiss, 2001; Beare ve Naylor, 1999).

\section{AVRUPA VE SINIRAŞAN ORGANIZE SUÇLAR}

Birçok bölgede farklı şekillerde ve farklı sebeplerden ötürü kendini gösteren bu tür suçların Avrupa'da varlık göstermesinin en temel sebebi Batı Avrupa ile Sovyetler Birliğinin ardından kurulan devletler ve Balkan coğrafyası arasındaki sosyo-ekonomik farktır (von Lampe, 2014:78). Çalışmanın bu kısmında, yol haritası olarak Europol tarafından 2017 yılında hazırlanmış olan Avrupa Birliği Ağır ve Organize Suç Tehdidi Değerlendirmesi (AB SOCTA) kullanılacaktır (Europol, 2017). Bu belgenin kullanımı çalışmaya hem direkt olarak AB'nin bu tür suçlara bakış açısını sağlayacak, hem de bu suçların kimliklerini ortaya koyacaktır. $\mathrm{Bu}$ noktada, sınıraşan organize suçların karakterlerini incelediğimiz zaman karşımıza üç tür çıkmaktadır. Bunlar: (1) bir şekilde uluslararası sınırları aşan yasadışı faaliyetler; (2) birden fazla ülkede varlık gösteren suç örgütleri; ve (3) yasadışı yönetişimin uluslararası sınırlara yayılması (von Lampe, 2014:76). Bu şekil de bir sinıflandırma Europol'ün değerlendirmesinde karşımıza çıkan suçları daha iyi anlamlandırma imkanı sunacaktır.

\section{A. Avrupa Birliği'nde Organize Suçlar: Eğilimler ve Trendler}

Aslına bakıldığında arz ve talep arasındaki ilişkiyle alakalı en temel iktisadi kanunu kullanarak oluşturulan organize suç sistemi dünyanın hemen her 
yerinde varlığını ortaya koymuştur. Bu bağlamda, ortaya konulan bu varlığ1 anlamak için, SOCTA ağır ve organize suç olarak tanımlanan faaliyetlere dair en temel üç soruyu cevaplayarak değerlendirmesine başlamıştır. Bu sorular: (1) suçu kimin veya kimlerin işlediği; (2) suçun nasıl işlendiği; ve (3) suç olarak gerçekleştirilen faaliyetlerin neler olduğu (Europol, 2017:13). Temelde sorulmas1 gereken bu sorulardan alınacak cevaplar, kolluk güçlerinin, diğer $\mathrm{AB}$ organlarının ve kurumlarının ve üçüncü tarafların politika yapım sürecinde etkin ve kapsamlı işbirliği yapmalarını sağlamaya yöneliktir.

Europol'e göre, organize suç örgütleri, suç ağları ve suç uzmanları, yolsuzluk, kolluk kuvvetlerine karşı önlemler, online ticaret, teknoloji, şiddet, evrakta sahtecilik ve para aklama yollarını kullanarak faaliyetlerini gerçekleştirirler. Ortaya çıkan faaliyetler ise, sahte para basmak, siber suçlar, uyuşturucu ticareti, sahtecilik, yasadışı atıkların ticareti, fikri mülkiyet haklarına karş1 suçlar, göçmen kaçakçılığı, emlak suçları, sporda yolsuzluk, tehlike altında olan türlerin ticareti, silah ticareti ve insan ticareti şeklinde karşımıza çıkmaktadır. Geniş bir hareket alanına sahip organize suçlar, Avrupa özelinde bakıldığında bu suçların akışı veya hareketliliği doğu-batı arasındadır. Suçun/suçların çıktılarına olan talebin geldiği yön Avrupa'nın neresi ise suç karşıt bölgeden başlayıp bu bölgede neticelenir. Örnek verecek olursak, çalıntı araçların suç içerisinde ki hareket yönü Batı Avrupa'dan Doğu Avrupa'ya doğrudur fakat cinsel istismar amaciyla yapılan insan ticareti veya sigara kaçakçılığının yönü ise Doğu Avrupa'dan Batı Avrupa'ya doğrudur (Antonopoulos ve Papanicolaou, 2009; Surtees, 2008; Europol, 2011:32-33). Yapılan çalışmalar ve yayınlanan haberlere göre, hiçbir ülke sınıraşan organize suçlara karşı bir bağışıklık geliştirememiştir. Örnek verecek olursak, Avrupa genelinde, Rus ve Türk mafyası ön plana çıarken, son dönemde özellikle uyuşturucu ticaretiyle kendilerini gösteren Arnavutlar, Kuzey Avrupa'ya yayılan motorlu çeteler ve Doğu Avrupa'da aktif olan Vietnamlı çeteler gün yüzüne çıkmıştır (Townsend, 2019: Burbank,2016: Portanova, 2018: Avrupa Parlamentosu, 2011). Daha önce belirtildiği gibi aslında organize suç örgütlerinin arz ettiği suç çıktıları var olan bir talebi karşılamaya yöneliktir. Fakat sadece ortaya çıkmış olan talep suçu ortaya çıkarmaya yetmez. $\mathrm{Bu}$ noktada, organize suç grupları teknolojiden, Avrupa'nın jeopolitik konumundan, suç için kilit noktalardan ve yasal işlerden destek alarak hem kendilerini güvende tutarlar hem de talebi karşılayabilirler (Europol, 2017:24).

$\mathrm{AB}$ içerisinde ki organize suç örgütlerine ve mafya benzeri yapılanmalara karş1@ON Operasyonel Ağ’ın bir parçası olarak 16-17 Nisan 2019 tarihinde düzenlenen üst düzey "Sınıraşan Organize Suçlarla Mücadele Stratejileri” isimli bir konferans düzenlenmiştir. Bu konferansta, AB'yi etkileyen organize suç örgütlerinin çeşitliliği, esnekliği ve hızlılı̆̆ 1 vurgulanmıştır. Konferansın amacı bilgi alışverişi yaparak, üst düzey suçluları izleme ve uluslararası soruşturmalara işaret etme yöntemleriyle gelişmiş uluslararası operasyonel polis işbirliğini sağlamaktır. Konferansın değerlendirmelerine göre, organize suç denilen olgu, büyük 'geleneksel' gruplardan, birlikte çalışan bireysel suçlular tarafından desteklenen daha küçük gruplara ve geleneksel gruplara göre daha gevşek ağlara 
sahip gruplara kadar uzanmaktadır. Birçok organize suç grubu işlerini yürütürken son derece esnektir ve gerçekte karmaşık ve birçok teknik bilgi gerektiren aktivitelerini ortamda bulunan değişikliklere göre ayarlayabilirler. Buna ek olarak, üst düzey organize suç örgütleri kamu ve özel sektör kuruluşlarına sızmak için yolsuzluğu kullanmaktadır (Europol, 2019).

Kullanılan bu yöntemler, örgütlerin dış şartlara adaptasyon kabiliyetleri tüm dünyayı etkilediği gibi AB'yi de etkilemektedir. Fakat, Europol'e göre en büyük risk $A B$ 'nin iç güvenliğine karşıdır. Organize suçlar sürekli yeni şartlara adapte olurken, özellikle AB'nin organize suçlarla iştirak eden suçluların varlıklarının takibi ve müsadere sonuçları hala düşük seviyelerde seyretmektedir. Europol'ün 2016 yılında yayınlamış olduğu rapora göre, 2012'den 2014'e kadar, $\mathrm{AB}$ genelinde tahmin edilen suç gelirlerinin sadece \%1.1'i ele geçirildi veya donduruldu (Europol, 2016:4). Bu durum pek tabi ki, örgütler için ciddi bir açıktır ve yasadışı faaliyetlerinin genişlemesinde önemli bir etkendir. Öyle ki, organize suç örgütlerinin gelirleri 2009 yılında yaklaşık olarak $\$ 870$ milyar ve küresel gayri safi hasılanın \%1,5'una tekabül ederken 2015/2016 yılları arasında organize suç gelirleri \$3.6-\$4.8 trilyon seviyelerine yükselerek ve küresel gayri safi hasılanın \%7'sini elinde tutar hale gelmiştir (Cartwright ve Bones, 2017:3; Bakowski, 2015:2). Bu büyüme 2000'li yıllara varılmadan AB tarafından görülmüş ve Avrupa Konseyi (1997:11) tarafından bu tür suçların 11 adet karakteristik özelliği ortaya konmuştur. Bunlar:

a. İkiden fazla kişinin işbirliği;

b. Her birinin kendine ait görevlerinin olması;

c. Uzun süreli veya süresiz olmas1;

d. Bir takım disiplin veya kontrol mekanizmaları kullanması;

e. Ciddi suçların işlendiğine dair şüphe duyulması;

f. Uluslararası düzeyde işlemler yapılması;

g. Şiddete ya da yıldırma için uygun diğer araçlardan yararlanma;

h. Ticari veya iş benzeri yapıları kullanma;

i. Kara para aklama;

j. Politika, medya, kamu yönetimi, adli makamlar veya ekonomi üzerinde etkili olma;

k. Kâr veya güç arayışıyla motive olma.

Fakat konsey bu 11 özelliğin tek başlarına bir hükmünün olmadığını vurgulayarak, içinde a,c,e ve k özelliklerin bulunduğu en az altı adedinin bir araya gelmesi durumunda organize suçun oluşabileceğinin altını çizmiştir. 1997 yılından bu yana $A B$ 'nin gündeminde ciddi bir yer işgal eden bu konu özellikle son dönemde uluslararası para ve mal transferlerinin kolaylaşması, teknolojide ki ilerlemeler, bölgesel çatışmalar ve krizler gibi etkenlerin kendilerini ciddi oranda göstermesi nedeniyle organize suç örgütleri bu kaotik ortamdan faydalanarak büyüme eğilimi içerisine girmişlerdir.

\section{B. Avrupa Birliği Ağır ve Organize Suç Tehdidi Değerlendirmesi}

Değerlendirme içerisinde vurgulanan suçların önlenmesine yönelik atılması gereken adımlara geçmeden önce, bu tür suçlarda trendlerin belirlenmesi 
bağlamında atılmış ve atılacak adımlara bakmak önemlidir. Trendleri anlamlandırabilmek bundan sonraki dönem için hazırlanacak değerlendirme belgelerinin okunmasını ve planlanmasını kolaylaştıracaktır. Organize suçlar en temelde üç farklı şekilde ortaya çıkmaktadır. Bunlar; yasadışı malların tedariki; yasadışı hizmetlerin tedariki; ve yasal işlerin istismarı veya yasal işler üzerinden nüfuz kullanma seklindedir (Albanese, 2003; Avrupa Konseyi, 2014:16). Bu şekillerde ortaya çıkabilen suçlar için fırsatlar yarattığı varsayılan bazı yapısal faktörler vardır. Bunlar, Birleşmiş Milletler Uyuşturucu ve Suç Ofisi'ne (BMUSO) göre devletler ve bölgeler arası kontrol, kaynak, ücret, yatırım ve hukuki asimetrilerdir (UNODC, 2018). Bu dengesizlikler günümüz şartlarında küreselleşmenin ve teknolojik gelişmelerin de katkısıyla büyük bir kazanç noktası olarak görülen organize suç faaliyetlerine zemin hazırlayarak, bu faaliyetlerin hem çok merkezli, hem de çok katılımlı bir karaktere sahip olmasını sağlamaktadır.

Küresel anlamda da kendini ciddi bir şekilde gösteren organize suçlarda ki bu genişleme $\mathrm{AB}$ için de söz konusu olduğundan, 2017 yılında hazırlanmış ve 2018-2021 yılları arasında AB'nin organize suçlarla ilgili adımlarına yön verecek bir yol haritası hazırlanmıştır. $\mathrm{Bu}$ yol haritası daha önce de belirtildiği gibi $\mathrm{AB}$ SOCTA 2017 olarak adlandırılmaktadır. 2017 yılına gelmeden önce AB'nin 2014-2017 yılları arasında ki konu ile ilgili önceliklerine, politikalarına bakmak 2017 sonrası dönem için politikaları değerlendirmekte bir zemin hazırlayacaktır. 2010 yılında $\mathrm{AB}$ bir politika döngüsü kurmuş ve 2013 yılında 4 yıllık bir periyodda başlatılmıştır. Bu politika döngüsü hem ulusal, hem de $\mathrm{AB}$ düzeyinde tüm tarafların muhtemel adımlarının şeklini ortaya koymaktadır (AB Konseyi, 2010). Bahsi geçen politika döngüsü dört elemandan oluşmaktadır ve AB'nin sonra ki dönemlerde de atacağı adımların temelini oluşturmaktadır. Bu dört eleman şu şekilde sıralanmıştır:

a. İçerisinde üye devletlerin ilgili birimlerine var olan ve gelecekte oluşabilecek olan organize suçları gösteren ve tavsiye niteliğinde öncelikli suçların altını çizen bir değerlendirme olan "Ağır ve Organize Suç Tehdidi Değerlendirmesi" (SOCTA);

b. Öncelikli suçların belirlenip bu suçlara yönelik "Çok Yıllı Stratejik Planlar" (MASP);

c. MASP'in belirlediği suçlarla ilgili "Operasyonel Eylem Planı" (OAP) ve bu planlara uygunluğun her altı ayda bir raporlanıp değerlendirilmesi;

d. Avrupa Komisyonu'nun değerlendirmesi ve ara raporlarla atılan adımların ve alınan derslerin incelenmesi.

Özetle bakacak olunduğunda, AB'nin organize suçlara yönelik politika döngüsü öncelikler, hedefler, eylemler ve tavsiyeler arasında sürekli bilgi toplanması şeklinde tasarlanmıştır. Bu bağlamda 2014-2017 yılları arasında belirlenen öncelikli suçlar ve üzerine adım atılması gereken konular ise: yasadışı göçmenlik; insan ticareti; sahte ürünlerin üretimi ve dağıtımı; vergide sahtecilik veya hırsızlık; sentetik uyuşturucuların üretimi ve dağıtımı; kokain ve eroin ticareti; siber suçlar; yasadışı silah ticareti; ve organize yürütülen emlak suçları 
olarak sıralanmıştır (Avrupa Konseyi, 2010:5). Bunun üzerine 2017 yılında ilk dönem politika döngüsünün başarılı olduğuna ve hedeflerine ulaştığına kanaat getiren AB, 2018-2021 yılları arasındaki dönem için aynı şekilde bir döngü hazırlamaya karar vermiştir. Bu bağlamda, 16 Mart 2017 yılında ağır ve organize suçlarla ilgili olarak bir hazırlık metni hazırlanarak 2018-2021 için içerikler belirlenmiştir (AB Konseyi, 2017). 18 Mayıs tarihinde ise öncelikler ve bu önceliklere dair hedefler belirlenerek AB Konseyi tarafindan 2018-2021 yılları için AB'ye bir yol haritası çizilmiştir. 10 adet ağır ve organize suç faaliyetinin altı çizilmiş ve bu yeni dönemde bu konular üzerine odaklanılması gerektiği vurgulanarak bu suçlara yönelik hedefler belirlenmiştir (Avrupa Konseyi, 2017).

Tablo 1. SOCTA Değerlendirmelerine Göre AB Konseyi’nin Belirlediği Öncelikli Suçlar

\begin{tabular}{ll}
\multicolumn{1}{c}{ 2014-2017 Yılları Arasında Dikkat Çekilen Suçlar } & 2018-2021 Yılları Arasında Dikkat Çekilen Suçlar \\
\hline Yasadışı göçmenlik & Siber suçlar \\
İnsan ticareti & Uyuşturucu ticareti \\
Sahte ürünlerin üretimi ve dağıtımı & Yasadışı göçün kolaylaştırılması \\
Vergide sahtecilik veya hırsılık & Organize hırsızlık ve soygun \\
Sentetik uyuşturucuların üretimi ve dağıtımı & İnsan ticareti \\
Kokain ve eroin ticareti & Vergide sahtecilik veya hırsızlık \\
Siber suçlar & Yasadışı silah ticareti \\
Yasadışı silah ticareti & Çevre suçları \\
Organize hırsızlık ve soygun & Suçun finansmanı ve kara para aklama \\
& Evrakta sahtecilik \\
\hline
\end{tabular}

Kaynak: AB Konseyi. (2017). The EU Policy Cycle to Tacle Organized and Serious International Crime. https://www.consilium.europa.eu/media/37340/20185274_qc0418775enn_pdf.pdf. Erişim tarihi: 18 Mart 2020.

Tablodan da anlaşılabileceği gibi daha önceki bölümlerde organize suçların yeni alanlara adaptasyonu iki ayrı dönem için hazırlanan değerlendirmelerde görülebilmekte. 2014-2017 yılları arasında AB'nin politikalarını yoğunlaştırması gereken suçlar arasında olmayan yeni suçlar 20182021 yılları arasında gündeme gelmiştir. Yeni dönem değerlendirmesinde çevre suçları, suçun finansmanı ve kara para aklama, ve evrakta sahtecilik suçları ağır ve organize suçlar arasına alınarak AB'nin politika döngüsüne alınmıştır

Tablo 2. SOCTA 2018-2021 Değerlendirmesine Göre Europol'ün Belirlediği

Öncelikli Suçlar ve Bu Suçlara Dair Hedefler

\begin{tabular}{ll}
\hline \multicolumn{1}{c}{ Öncelikli Suçlar } & \multicolumn{1}{c}{ Hedefler } \\
\hline Siber suçlar & -bilgi sistemlerine yönelik saldırılarla ilgili cezai faaliyetlerin \\
& aksatılmasının önüne geçilmesi \\
& -çocuk cinsel istismarı ve çocuk cinsel sömürüsü ile mücadele \\
& etmek \\
& -nakit dışı ödeme yöntemlerinin sahteciliği önlemek ve \\
& sahteciliğe karışan suçluları yakalamak \\
& -AB'ye esrarın, kokainin ve eroinin toptan ticareti ile ilgili \\
Uyuşturucu ticareti & organize grupların faaliyetlerini kesmek \\
& - AB pazarlarında birden fazla tür uyuşturucu maddenin \\
& ticareti ve dağıtımında yer alan suç ağları ile mücadele etmek \\
& -AB'de sentetik uyuşturucu ve yeni psikoaktif maddeler \\
& üretimini azaltmak \\
& AB sinırındaki ve AB içindeki ana göç yolları boyunca \\
düzensiz göçmenlere kolaylaştırıcı hizmetler sunarak yasadışı & göçü kolaylaştıran organize suç gruplarının faaliyetlerini \\
Yasadışı göçün kolaylaştırılması & engellemek \\
AB genelinde organize hırsılılı ve soygunları gerçekleştiren \\
yüksek düzeyde mobil organize suç gruplarını engellemeye \\
odaklanarak örgütlü mülkiyet suçuyla mücadele etmek.
\end{tabular}




\begin{tabular}{|c|c|}
\hline İnsan ticareti & $\begin{array}{l}\text { AB sı̈ırları içerisinde insan ticareti ile cinsel istismar, işçi } \\
\text { sömürüsü ve çocuk ticareti gibi her türlü sömürü için } \\
\text { mücadele etmek. }\end{array}$ \\
\hline Vergide sahtecilik veya hırsızlık & $\begin{array}{l}\text { Organize suç örgütlerinin finansal kapasitelerini kırmak için } \\
\text { vergi kaçırmaya veya vergide sahteciliğe engel olmak. }\end{array}$ \\
\hline Yasadışı silah ticareti & $\begin{array}{l}\text { Organize suç örgütlerinin dahil oldukları yasa dışı silah } \\
\text { ticaretini, silahların dağıtımını ve kullanılmasını engellemek. }\end{array}$ \\
\hline Çevre suçları & $\begin{array}{l}\text { Çevre suçlarına, özellikle de vahşi yaşam ve yasadışı atık } \\
\text { ticaretine karışan organize suç gruplarının faaliyetlerini } \\
\text { engellemek. }\end{array}$ \\
\hline Suçun finansmanı ve kara para aklama & $\begin{array}{l}\text { Suçun finansmanı ve kara para aklama ile mücadele etmek ve } \\
\text { organize suç gruplarının suç kârlarına etkin bir şekilde el } \\
\text { koymak için varlıkların haciz edilme işlemini kolaylaştırmak. }\end{array}$ \\
\hline Evrakta sahtecilik & $\begin{array}{l}\text { AB'deki belge sahtekarlığıyla mücadele etmek için, diğer } \\
\text { suçlulara hileli ve sahte belgelerin üretimi ve sunumunda yer } \\
\text { alan organize suç gruplarını hedeflemek. }\end{array}$ \\
\hline
\end{tabular}

Kaynak: Europol, (2017). EU serious and organised crime threat assessment (EU SOCTA).
https://www.europol.europa.eu/activities-services/main-reports/european-union-serious-and-organised-crime-
threat-assessment-2017 Erişim tarihi: 18 Mart 2020

2018-2021 değerlendirmesinde altı çizilen suçlara karşı benimsemesi planlanan hedefler ise tabloda gösterildiği gibi vurgulanmıştır. Organize suç faaliyetlerinin engellenmesine dair atılması hedeflenen bu adımlar temelde bu suçlarla ilgilenen örgütlerin yasa dışı piyasalarda oluşan talebi karşılayamamasını sağlamayı hedeflemektedir. Diğer bir ifade ile örgütlerin arz etmelerini engelleyerek veya zorlaştırarak denklemin talep tarafında bir düşüş sağlamak vasıtasıyla bu tür suçların karlıığını azaltmaktır. Bu suçlara ek olarak, 2018-2021 değerlendirmesi spor faaliyetleri içerisinde son dönemde Avrupa da bulunan kulüplerin bir takım yolsuzluklara (şike, teşvik primleri) gitmeleri konusuna da dikkat çekmiş ve bu gibi durumları kara para aklama suçunun bir yolu olarak görmüştür (Europol, 2017:54). Değerlendirme içerisinde ki en dikkat çekici noktalarda birisi ise, Brüksel'de ve Paris'te 2015 ve 2016 yıllarında gerçekleşen terör faaliyetlerinin ardından bazı eylemcilerin organize suç örgütlerinin üye olduğunun tespit edilmesi ile organize suç faaliyetleri ile terörü birbirlerine ilişkilendirmesidir. $\mathrm{Bu}$ ilişkiyi iki yönlü olarak adlandırarak hali hazırda değerlendirme içerisine aldığ 1 iki organize suç faaliyetiyle birleştirmiştir. Bu iki yönlü ilişkinin ilk kısmı, organize suç örgütlerinin ticaretini ve dağıtımını yaptığ yasa dışı silahların terör eylemlerinde kullanılmasıdır. İkinci kısımda ise, organize suç örgütlerinin yürüttükleri yasa dışı ticaretlerden elde ettikleri gelirleri terörün finansmanı için kullanma ihtimalidir (Europol, 2017:55). Değerlendirmede bahsedilen bu ilişkiler 10 Nisan 2002 tarihinde yürürlüğe girmiş olan BM Terörizmin Finansmanının Önlenmesi Sözleşmesi içerisinde de vurgulanmıştır. $\mathrm{Bu}$ bakımdan $\mathrm{AB}$ özellikle değerlendirmenin taslak haline getirilme sürecinde iki büyük başkent olan Brüksel ve Paris'teki saldırılara bir refleks olarak organize suç örgütleri ile terör konularını yan yana getirerek hafıza tazelemiştir.

\section{SONUÇ}

Organize suçlar konusu her ne kadar uzun bir geçmişe sahip olmasa da günümüzde ortaya çıkarttığı etkiler neticesinde hem ulusal düzeyde, hem de uluslararası düzeyde devletlerin odak noktalarından biri haline gelmiştir. Organize suçlarla ilgili olarak literatürde ki yaklaşımlar konunun yasadışı bir faaliyetler 
bütünü olmasının ve aynı zamanda bir ihtiyaçtan doğduğu gerçeğinin altını çizmektedir. Özellikle küreselleşmenin gelişimiyle bağdaştırılan organize suçların gelişim dönemi aslında bu tür suçların tipik bir arz-talep ilişkisinden doğduğunu ve varlığını sürdürdüğünü kanıtlamaktadır. Özellikle BM Sınıraşan Organize Suçlar Sözleşmesinin ardından bir tanıma ve bu tanımla beraber kavramsal bir çerçeveye kavuşan organize suçlar dünyanın her yerinde kendini gösteren, bölgesel ihtiyaçlara yönelik faaliyet geliştiren bir suç olgusu olarak günümüzde de varlığını ve metotlarını dış çevreye adapte ettirebilen bir sistemdir.

$\mathrm{Bu}$ doğrultuda, çalışmanın içeriğine konu olan $\mathrm{AB}$ sınırları içerisinde de alınan tüm önlemlere ve politikalara rağmen organize suç olgusu kendini ciddi şekilde göstermektedir. AB içerisinde meydana gelen organize suç faaliyetleri de suçun çıktılarına olan talebin yönü doğrultusunda ya doğu-batı eksenli ya da bat1doğu eksenli olarak ortaya çıkmaktadır. Organize suç örgütleri, suç ağları ve suç uzmanları, yolsuzluk, kolluk kuvvetlerine karşı önlemler, e-ticaret, teknoloji, şiddet, evrakta sahtecilik ve para aklama yollarını kullanarak faaliyetlerini gerçekleştirirler. Bu faaliyetler konusunda 2010 yılında ilk adımı atılan ve 20142017 yılları arasında organize suçlarla ilgili olarak AB'nin yol haritasını çizen ve politikalarına şekil veren bir süreç değerlendirmesi hazırlanmıştır. Ağır ve Organize Suç Tehdidi Değerlendirmesi kolluk güçlerinin, diğer AB organlarının ve kurumlarının ve üçüncü tarafların yasadışı göçmenlik, insan ticareti, sahte ürünlerin üretimi ve dağıtımı, vergide sahtecilik veya hırsızlık, sentetik uyuşturucuların üretimi ve dağıtımı, kokain ve eroin ticareti, siber suçlar, yasadışı silah ticareti ve organize hırsızlık ve soygun suçları ile ilgili olarak işbirliği yapıp bu suçların engellenmesini hedeflemiştir. 2014-2017 periyodunun nihayete ermesine yakın 2018-2021 yılları arasındaki dönem için bir değerlendirmenin hazırlıklarına başlanmış ve ortaya 2018-2021 Ağır ve Organize Suç Tehdidi Değerlendirmesi çıkmıştır. Faaliyetlerini piyasanın gereklerine göre hızlı ve esnek şekilde adapte edebilen organize suç örgütlerinin bu becerileri $A B$ tarafından görülmüştür. Bu bağlamda 2018-2021 yılları arası dönemin hedeflerini ortaya koyan değerlendirme bu esnekliğe uyum sağlamak için daha kapsamlı hale getirilmiştir. Bir önceki değerlendirmeye göre AB'nin hedef aldığı suçların sayısı bir öncekine göre artmış ve çevre suçları, suçun finansmanı ve kara para aklama, ve evrakta sahtecilik suçları da artık göz önünde bulundurulması gereken suçlar haline getirilmiştir.

Özüne bakıldığında iktisadi bir süreç olan organize suç faaliyetleri, doğurduğu ekonomik ve sosyal neticeler itibariyle yıkıcıdır. Bu bağlamda, AB'nin Europol kanalıyla hazırlamış olduğu yol haritaları ve bu yol haritalarında uyulması gereken süreçleri belirleyen politika döngüleri organize suçlarla mücadele etmek için önemli adımlardır. Fakat çalışma içerisinde sıkça tekrarlanmış olan gerçeklik göz ardı edilmemelidir. Bu suçlar arz ve talep arasında ilerlemektedir. Bu durumda, talebin ortadan kaldırılmasına yönelik hem siyasi, hem hukuki hem de kültürel normlar geliştirmek suç faaliyetlerini hem zorlaştıracak hem de karlı olmaktan çıkartacaktır. 


\section{Açıklamalar}

1. "Sınıraşan(transnational): extending or going beyond national boundaries- ulusal sınırların ötesine geçip genişlemek anlamında kullanılmaktadır" bu tanıma karşılık "uluslararası (international): of, relating to, or affecting two or more nations - iki veya daha fazla ulusu etkileyen ve iki veya daha fazla ulusu ilgilendiren anlamında kullanılmıştır."

2. 15 Kasım 2000 yılında Birleşmiş Milletler Genel Kurulu 55/25 sayılı kararı vasitasıyla kabul edildi ve 19 Eylül 2003 yılında 147 üye devletin imzasiyla yürürlüğe girmiştir. Sın/raşan Örgütlü Suçlara Karşı Birleşmiş Milletler Sözleşmesine Ek insan Ticaretinin Özellikle Kadın ve Çocuk Ticaretinin Önlenmesine, Durdurulmasına ve Cezalandırılmasına ilişkin Protokol, Ek Kara, Deniz ve Hava Yoluyla Göçmen Kaçakçılığına Karşı Protokol ve Ek Ateşl Silahlar, Parçaları ve Aksamları ile Mühimmatının Yasadışı Üretimine ve Kaçakçılığına Karşı Protokol.

\section{KAYNAKÇA}

AB Konseyi. (2017). The EU Policy Cycle to Tacle Organized and Serious International Crime. https://www.consilium.europa.eu/media/37340/20185274_qc0418775enn_pdf.pdf. Erişim tarihi: 18 Mart 2020.

Albanese, J. (2003). The Prediction and Control of Organized Crime: A Risk Assessment Instrument for Targeting Law Enforcement Efforts. (National Criminal Jusiice Reference Service (NCJRS), Doc. no. 199047, Award no. 2000-IJ-CX-0009). https://www.ncjrs.gov/pdffiles1/nij/grants/199047.pdf. Erişim tarihi: 20 Mart 2020.

Albanese,J. (2005).North American organised crime. (Edited by Galeotti M), Global Crime Today: The Changing Face of Organised Crime. London: Routledge 8-18.

Andres,P. (2002). Transnational crime and economic globalization, (Edited by M. Berdal ve M. Serrano). Transnational organized crime and international security : business as usual? London: Lynne Rienner Pub, 37-52.

Antonopoulos, G. A. ve Papanicolaou, G. (2009). Gone in 50 seconds: The social organisation and political economy of the stolen cars market in Greece. (Edited by P. C. van Duyne, S. Donati, J. Harvey, A. Maljevic, \& K. von Lampe), Crime, money and criminal mobility in Europe. Nijmegen: Wolf Legal, 141-174.

Avrupa Konseyi. (2010). The EU Policy Cycle To Tacle Organised and Serios International Crime. https://www.consilium.europa.eu/media/30232/qc0114638enn.pdf. Erişim tarihi: 19 Mart 2020.

Avrupa Konseyi. (2014). Draft Council Conclusions on the continuation of the EU Policy Cycle for organised and serious international crime for the period 2018-2021 (Doc 9450/17). http://data.consilium.europa.eu/doc/document/ST-7093-2017-INIT/en/pdf. Erişim tarihi: 19 Mart 2020.

Avrupa Konseyi. (2017). Infographic - EU fight against organised crime: 2018-2021. https://www.consilium.europa.eu/en/infographics/organized-crime/. Erişim tarihi: 19 Mart 2020.

Avrupa Konseyi.(1997). Doc. 6204/2/97 Enfopol 35 Rev 2, based on doc. 8469/1/99. http://data.consilium.europa.eu/doc/document/ST-10415-2000-INIT/en/pdf. Erişim tarihi: 19 Mart 2020.

Avrupa Parlamentosu. (2011). Asian organized crime in the European Union. Brüksel: European Parliament.

Bakowski, P. (2015). Organised crime in the European Union. https://www.europarl.europa.eu/RegData/etudes/BRIE/2015/569039/EPRS_BRI(2015)56 9039_EN.pdf. Erişim tarihi: 03 Mart 2020.

Beare, M. ve Naylor, R. (1999). Major Issues Relating to Organized Crime : within the Context of Economic Relationships.

(Nathanson Centre). 
https://dalspace.library.dal.ca/bitstream/handle/10222/10284/Nathanson\%20Centre\%20Re search $\% 20$ Economic\%20and\%20Organized\%20Crime\%20EN.pdf?sequence $=1$. Erişim tarihi: 19 Mart 2020.

Burbank, J. (2016). Organized Crime in Europe: A country-By-Country Breakdown. https://themobmuseum.org/blog/organized-crime-in-europe-a-country-by-countrybreakdown/. Erişim tarihi: 13 Mart 2020.

Carteright, R. ve Bones, F. (2017). Transnational Organized Crime and the Impact on the Private Sector: The Hidden Battalions. Cenevre: Global Initiative against Transnational Organized Crime.

Devito, C. (2005). The Encyclopedia of International Organized Crime. New York: Facts on File.

Dorr, G. ve Simpson, S. (1931). Summary and Recommendations. (Edited by Wickersham Commission), Report on the Cost of Crime. Washington: United States Government Printing Office, 438-453.

Europol. (2011). EU organised crime threat assessment: OCTA 2011. The Hague, the Netherlands: European Police Office.

Europol. (2013). Socta 2013: EU Serious and Organised Crime Threat Assessment. The Hague, the Netherlands: European Police Office.

Europol. (2016). Does crime still pay?.https://www.europol.europa.eu/publications-documents/doescrime-still-pay. Erişim tarihi: 02 Mart 2020.

Europol, (2017). EU serious and organised crime threat assessment (EU SOCTA). https://www.europol.europa.eu/activities-services/main-reports/european-union-seriousand-organised-crime-threat-assessment-2017. Erişim tarihi: 23 Şubat 2020.

Europol. (2019). Fighting Transnational Organised Crime: Europol and The Italian Anti-Mafia Investigation Directorate Host First Operational Conference in The Hague. https://www.europol.europa.eu/newsroom/news/fighting-transnational-organised-crimeeuropol-and-italian-anti-mafia-investigation-directorate-host-first-operational. Erişim tarihi: 12 Mart 2020.

Felsen,D. ve Kalaitzidis, A. (2005). A Historical Overview of Transnational Crime, (Edited by Philip Reichel), Handbook of Transnational Crime \& Justice. Londra: Sage Publications, 3-19.

Gachuz, J.C. (2016). Globalization and Organized Crime: Challenges for International Cooperation (Rice Univercity's Baker Institute for Public Policy Issue Brief). https://www.bakerinstitute.org/media/files/files/37efaacf/BI-Brief-070616MEX_Globalization.pdf. Erişim tarihi: 22 Mart 2020.

Hall,T. (2012). Geographies of the illicit: Globalization and organized crime. Progress in Human Geography, Vol.37, Iss.3, 366-385. DOI: 10.1177/0309132512460906.

Interpol. (1998). Annual activity report AGN / 68/ RAP/1. https://www.interpol.int/content/download/4922/file/Annual\%20Report\%201998-EN.pdf. Erişim tarihi: 28 Şubat 2020.

Louise, S. (1995). Transnational Organized Crime: An Imminent Threat to the Nation-State? Journal of International Affairs, Vol.48, Iss.2, 463-489.

Lupsha, P.A. (1996). Transnational organized crime versus the nation-state. Transnational organized crimei, Vol.2, Iss.1, 21-48.

Madsen,M. (2009). Transnational Organized Crime. London: Routledge.

Mittelman, J.H. (1999). The Globalization of Organized Crime, the Courtesan State, and the Corruption of Civil Society, Global Governance, Vol.5, 103-126.

Nadelmann, E.A. (1993). Cops across borders: The internalization of U.S. criminal law enforcement. Pensilvanya, Pennsylvania State University Press.

Nordstrom, C. (2007). Global Outlaws: Crime, Money, and Power in the Contemporary World. Berkeley: University of California Press.

Orlova, A. V. ve Moore, J. W. (2005). Umbrellas or building blocks: Defining international terrorism and transnational organized crime in international law. Houston Journal of International Law. Vol.27, Iss.2, 267-310. 
Portanova, M. (2018). United Mafias of Europe: what is lacking to fight crime in EU Interactive Map: the presence of clans in each Member State. https://www.ilfattoquotidiano.it/longform/mafia-and-organized-crime-in-europe/map/. Erişim tarihi: 19 Mart 2020.

Sabatino,M. (2016). The processes of globalization and transnational organized crime. Journal of International Business and Economics, Vol.16, Iss.2, 61-82.

Serrano,M. (2002). Transnational organized crime and international security : business as usual?, (Edited by M. Berdal ve M. Serrano). Transnational organized crime and international security : business as usual?. London: Lynne Rienner Pub., 13-36.

Surtees, R. (2008). Traffickers and trafficking in Southern and Eastern Europe: Considering the other side of human trafficking. European Journal of Criminology, Vol.5, Iss.1, 39-68.

Syring, T. (2012). Candide, or Pessimism: Fighting Piracy and Transnational Crime in Uncharted Waters, Interdisciplinary Political Studies, Vol.2, Iss 1, 48-58.

Townsend, M. (2019). Kings of cocaine: how the Albanian mafia seized control of the UK drugs trade. (The Guardian, 14 Ocak 2019). https://www.theguardian.com/world/2019/jan/13/kings-of-cocaine-albanian-mafia-ukdrugs-crime. Erişim tarihi: 19 Mart 2020.

UNODC. (2010). The Globalization of Crime: A Transnational Organized Crime Threat Assessment. New York: United Narions Press.

UNODC. (2018). Organized Crime. https://www.unodc.org/e4j/en/organized-crime/module-6/keyissues/structural-factors.html. Erişim tarihi: 02 Şubat 2020.

van der Wilt, H.G. (2014). Trafficking in human beings: a modern form of slavery or a transnational crime?, Amsterdam Law School Legal Studies Research Paper No. 2014-13, Amsterdam: University of Amsterdam.

Vlasis, D. (2002). The UN Convention Against Transnational Organized Crime. (Edited by M. Berdal ve M. Serrano). Transnational organized crime and international security: business as usual?. London: Lynne Rienner Pub, 83-94.

von Lampe, K. (2014). Transnational Organized Crime in Europe. (Edited by J. Albanese ve Philip Reichel). Transnational Organized Crime An Overview from Six Continents. Londra: Sage Publication, 75-92.

Williams, P. (2012). How Globalization Affects Transnational Crime. Council on Foreign Relations interview with Stewart M. Patrick. http://www.cfr.org/ transnational crime/globalizationaffectstransnational-crime/p28403. Erişim tarihi: 02 Mart 2020.

Woodiwiss, M. (2001). Organized Crime and American Power: A History. Toronto: University of Toronto Press.

Wright, A. (2005). Organised Crime. Devon: Willian Publishing.

\section{SUMMARY}

Organized crime is an illegal activity carried out by criminal networks for profit. In every side of the World, these activities may be appeared with various faces for meeting the demand. This study primarily focuses on the conceptual framework of organized crime and its activity methods. As a result of the outputs of the researches conducted by various scholars, the study highlights two complicated issues on organized crime. First, the nature of organized crime has highly adaptive to changes in environmental situations, such as operational capacity of law enforcement office, political structure instability of target and rapidly changing demands. Second, organized crime is associated not only with illegal activities but also with legitimate businesses. For instance, to be realized money laundering or corruption, the existence of a legal business or financial institution is crucial. 
In the context of the outputs of literature review, the study concentrates on organized crime activities in the EU in order to create more sophisticated and comprehensive work not only to analyse the trends and tendencies in organized crime but also to evaluate policies and plans against it. In this respect, this study concentrates on organized crime activities and their perpetrators' actions from the perspective of the EU. After that point, in order to interpret the steps of the EU in more detail, the study examines the EU Policy cycles and "Serious and Organized Crime Treat Assessments (SOCTA)". The history of the tools is not far back. In 2010, because of rapid increase in organized crime activities in the EU, Europol prepared first policy cycle. It has four vital steps: (1)SOCTA which underlines possible primary crimes; (2) Multi Annual Strategic Plans (MASP) which determines the primary crimes; (3) Operational Action Plans (OAP) which prepares biannual reports in order to evaluate the steps against primary crimes; and (4) examination. As a consequence of this policy cycle, in 2013, Europol has prepared "SOCTA 2014-2017" to reveal declared the primary organized crime activities in this period (Europol, 2013: 18-31). According to the assessment, facilitation of illegal immigration, trafficking in human beings, counterfeit goods, excise and MTIC (Missing Trader Intra Community) fraud, synthetic drugs, cocaine and heroin trafficking, cybercrime, illicit firearms trafficking and organised property crime have been considered as main focal points of the EU for the period of 2014-2017. Due to the ability of organized crimes to adapt to environmental factors, the EU knows that aforementioned tools should have been compatible with external factors. To assort with the changing characteristics of organized crime, Europol has prepared SOCTA 2018-2021 in 2017. According to this assessment, three primary crimes, which are environmental crimes, money laundering and financing of terror related activities, have been added to the previous assessment. These new crimes are indicative of the compatibility of the evaluations. After the terrorist attacks in Brussels and Paris, Europol has bring to the fore particularly the criminal finance or financial supports to terrorist activities issues for the assessment for the period 2018-2021.

The study has drawn the conceptual framework of organized crime phenomenon by examining the related literature, and then evaluated the changes of organized crime tendencies within the EU by comparing the assessments for 2014-2017 and 2018-2021 prepared by Europol. The result of the evaluations shows that both organized crime activities and tools developed by the EU against organized crime vary according to the state of time and environment. This result and the method of achieving this result have added to the study the unique feature. 